ISSN : 2621- 1475

\title{
STUDI PERUBAHAN BIOKIMIA DAN MIKROBIAL UDANG VANAME (Litopenaeus vannamei) SELAMA PROSES RANTAI DINGIN DI PERUSAHAAN GRAHAMAKMUR CIPTAPRATAMA KABUPATEN KONAWE
}

\author{
Tri Adiyat Badrin *, Andi Besse Patadjai, Suwarjoyowirayatno \\ Jurusan Teknologi Hasil Perikanan Fakultas Perikanan dan Ilmu Kelautan Universitas Halu Oleo, Jalan H.E.A \\ Mokodompit Kampus Bumi Tridharma Anduonohu, Kendari 93232 Sulawesi Tenggara \\ Telepon +6282291447167 \\ *Korespondensi: atleastyoutriad@yahoo.co.id \\ Diterima: 1 April 2019/Disetujui: 8 April 2019
}

Cara sitasi: Badrin TA, Patadjai A, Suwarjoyowirayatno. 2019. Studi perubahan biokimia dan mikrobial udang vaname (Litopenaeus vannamei) selama proses rantai dingin di perusahaan Grahamakmur Ciptapratama Kabupaten Konawe. Jurnal Fish Protech. 2(1): 59-68.

\begin{abstract}
Abstrak
Tujuan dari penelitian ini adalah untuk mengetahui perubahan biokimia dan mikrobial udang putih (L. vannamei) selama proses penanganan di bawah sistem rantai dingin mulai dari penerimaan dari pemasok hingga pembekuan. Penelitian ini menggunakan Rancangan Acak Kelompok (RAK) dengan 5 perlakuan yaitu sampel udang yang didapat dari Receiving (P1), Deheading (P2), PND (P3), Washing III (P4) dan Freezing (P5) serta 3 kali ulangan. Ulangan berupa kelompok supplier yang berbeda.Perubahan biokimia yang diukur meliputi suhu, $\mathrm{pH}$, TVB dan TMA dan perubahan mikroba dengan menguji TPC. Analisis proksimat dilakukan sebagai data produk pendukung. Hasil penelitian menunjukkan terdapat perbedaan yang signifikan dalam hal suhu, TVB, TMA dan TPC. Rata-rata nilai pH tetap stabil dikisaran netral (6.8-7.0). Tingkat TVB-N dan TMA-N pada semua aliran proses sangat rendah. Receiving (P1) memiliki nilai TVB-N dan TMA-N tertinggi yaitu $10,31 \mathrm{mgN} / 100$ gr dan 3,75 mgN/100 gr. Tingkat TVB-N dan TMA-N menurun secara signifikan seiring dengan berlanjutnya proses perlakuan. Tingkat TPC tertinggi pada Receiving (P1) 7,2 x $104 \mathrm{CFU} / \mathrm{g}$ dan terendah pada Deheading (P2) 1,9 x $104 \mathrm{CFU} / \mathrm{g}$. Kadar air udang putih meningkat dari (P1) 79,78\% menjadi 82,53\% (P5). Senyawa Protein meningkat dari (P1) 61,78\% (basis kering) menjadi 74,93\% (basis kering) (P5). Mereka menunjukkan bahwa pembekuan cepat dengan CPF memiliki dampak yang baik pada kualitas biokimia, mikroba dan juga proksimat.
\end{abstract}

Kata kunci: Biokimia, mikrobial, rantai dingin, udang beku 


\title{
STUDY OF BIOCHEMICAL AND MICROBIAL CHANGES WHITE SHRIMP (Litopenaeus vannamei) DURING COLD CHAIN SYSTEM AT PT. GRAHAMAKMUR CIPTAPRATAMA KABUPATEN KONAWE
}

\begin{abstract}
The aim of this research was to study the biochemical and microbial changes of White Shrimp (L. vannamei) during handling under cold chain system starting from receiving from suppliers until freezing. There were five steps as source of variation and act as treatment. These were using three replications. These arranged under random block design. The sources of Variation were: Receiving (P1); Deheading (P2), Peeled and Deveined (P3), Washing III (P4), and Freezing (P5). The biochemical changes were monitored consist of temperature, $\mathrm{pH}, \mathrm{TVB}$ and TMA and the microbial changes were monitored by TPC. The proximate was also analyzed as supporting product data. The result of the experiment shown there was significantly different in term of temperature, TVB, TMA and TPC. The result shown that the average of $\mathrm{pH}$ remained stable in the neutral range (6.8-7.0). The result shown the level of TVB-N and TMA-N on all process flow was very low. Receiving (P1) was the highest level of TVB-N and TMA-N consecutively $10.31 \mathrm{mgN} / 100$ gr and 3.75 mgN/100 gr. The level of TVB-N and TMA-N decreased significantly continuously with the process. The highest level of TPC was Receving (P1) $7.2 \times 10^{4} \mathrm{CFU} / \mathrm{g}$ and the lowest was Deheading (P2) $1.9 \times 10^{4} \mathrm{CFU} / \mathrm{g}$. The moisture of white-leg shrimp increased from (P1) $79.78 \%$ to $82.53 \%$ (P5). The Protein compound increased from (P1) $61.78 \%$ (dry basis) to $74.93 \%$ (dry basis) (P5). Those indicated that quick freezing with CPF had a good impact on the quality of biochemical, microbial and also proximate.
\end{abstract}

Key words: Biochemical, microbial, frozen shrimp, cold chain

\section{PENDAHULUAN}

Indonesia merupakan produsen utama udang dunia, khususnya untuk jenis udang vaname (Litopenaeus vannamei). Udang merupakan komoditas yang dihasilkan melalui kegiatan budidaya. Produksi udang untuk Sulawesi Tenggara dari hasil budidaya pada tahun 2012 yaitu 14.000 ton. Produksi udang tahun 2013 meningkat menjadi 18.000 ton. Presentasi menunjukkan bahwa dari tahun 2012 hingga tahun 2013 mengalami peningkatan produksi yaitu $22,2 \%$ (KKP 2014). Perikanan budidaya mampu memberikan kontribusi yang besar pada peluang usaha dan perolehan devisa.

Udang merupakan salah satu
komoditas utama yang diminati
masyarakat sebagai bahan makanan
karena dagingnya yang gurih, rasanya
lezat dan kandungan gizinya yang tinggi.
Udang merupakan salah satu bahan
makanan dari produk perikanan yang
dapat memenuhi gaya hidup serta pola
konsumsi pangan. Kebutuhannya di masa
mendatang diprediksi melampaui 50\%
kebutuhan protein hewani masyarakat
dunia $3 \mathrm{~g} / \mathrm{kg}$ berat badan per hari atau
sekitar $54 \mathrm{~kg} / \mathrm{kapita} / \mathrm{tahun}(\mathrm{DKP}, 2005)$.
Tantangan yang dihadapi oleh
perusahaan pengekspor udang semakin
besar. Konsumen umumnya telah


mempunyai kesadaran yang tinggi akan produk yang aman dan berkualitas. Berbagai peraturan yang dikeluarkan oleh negara pengimpor atau lembaga terkait mengenai tata niaga udang juga cukup menjadi hambatan. Selain persyaratan mutu produk yang harus dipenuhi, perusahaan juga harus memenuhi kualifikasi yang ditentukan agar dapat memasarkan produknya di negara yang bersangkutan. Perusahan masih juga harus bersaing dengan sesama produsen dari berbagai negara untuk memperebutkan pasar yang ada dapat menjawab berbagai tantangan tersebut.

Dengan memenuhi persyaratan dalam penanganan maupun pengolahan, maka diharapkan hasil pengolahan dapat memenuhi standar mutu yang ditetapkan baik secara nasional maupun internasional. Kontinuitas mutu produk sangat penting guna meningkatkan kepercayaan luar negeri terhadap mutu suatu produk sehingga produk tersebut dapat ditemui di pasar Internasional. Oleh karena itu, produsen/pengolah harus semaksimal mungkin melakukan penanganan terhadap kemunduran mutu produk dan menjaga kualitas produk yang dihasilkan.

Mengingat sifat udang yang mudah busuk, maka pengendalian mutu mutlak dilakukan dalam industri perikanan terutama karena produk perikanan cepat mengalami kemunduran mutu. Pembusukan komoditi perikanan dimulai pada saat ikan mati yang menyebabkan perubahan kimia, fisika, mikrobiologi dan histologi yang terjadi pada serat otot. Proses ini biasanya bersamaan dengan hilangnya sedikit demi sedikit kandungan gizi yang berimbas kepada kualitas dari komoditi perikanan, perubahan kualitas dipengaruhi beberapa faktor, terutama suhu. Apabila suhu tidak terkontrol dengan baik akan berdampak pada kemunduran mutu komiditi perikanan.

Kemunduran tersebut terutama diakibatkan oleh adanya aktivitas mikroorganismeyang mengkontaminasi udang, baik sewaktu masih berada di tambak maupun kontaminasi selama proses produksi. Keberadaan mikroorganisme pada produk juga berkaitan erat dengan masalah keamanan pangan. Oleh karena itu, penanganan udang selama pengolahan harus mampu menekan kandungan mikroorganisme yang ada pada udang, sehingga dapat menghambat laju kerusakan mutunya. Untuk mengahambat laju kerusakkan mutu dapat dilakukan dengan cara menerapkan cold chain system.

Prinsip umum cold chain system adalah menurunkan suhu melalui media yang dapat menyerap panas dari tubuh udang, sehingga suhu udang menjadi rendah (dingin). Disamping itu pula, suhu dingin dapat menghambat pertumbuhan bakteri penyebab kemunduran mutu udang karena tidak tersedianya lingkungan yang cocok untuk aktivitas bakteri. Cold chain system dapat diterapkan dengan menggunakan es atau pembekuan. Pembekuan udang merupakan salah satu cara memperlambat terjadinya proses penurunan mutu, baik secara autolisis, bakteriologis atau oksidasi dengan suhu dingin, walaupun dapat menghambat pertumbuhan mikroorganisme serta memperlambat reaksi kimia dan aktivitas enzim, pembekuan bukanlah cara untuk mensterilkan udang. Oleh karena itu, sesudah udang dibekukan dan disimpan dalam cold storage (ruang beku), tidak akan lepas begitu saja dari proses penurunan mutu (Purwaningsih, 1995). 
Berdasarkan uraian di atas, maka perlu dilakukan suatu penelitian tentang perubahan biokimia dan mikrobial udang vaname (Litopenaeus vannamei) beku pada proses rantai dingin yang diproduksi di perusahaan GMCP Kabupaten Konawe.

Tujuan dari penelitian ini yaitu untuk mengetahui perubahan biokimia dan mirkobial udang vaname (L. vannamei) sejak penerimaan dari supplier hingga pembekuan.

\section{BAHAN DAN METODE}

\section{Bahan dan Alat}

Bahan utama yang digunakan dalam penelitian ini adalah udang vaname (L. vannamei) yang diambil di ruang processing. Bahan yang digunakan untuk uji TVB dan TMA yaitu Tricloroacetic Acid (TCA) 7\%, $\mathrm{H}_{3} \mathrm{BO}_{3}, \mathrm{~K}_{2} \mathrm{CO}_{3}$ Jenuh, $\mathrm{HCl} 0,021 \mathrm{~N}$, kertas saring, indikator Tashiro. Bahan yang digunakan untuk uji TPC meliputi Plate Count Agar, alkohol 70\%, kapas, Potassium Dihydrogen Phosphate, Butterfield's Phosphate Buffered, NaOH, Akuades. Bahan yang digunakanuji proksimat meliputi aquades, $\mathrm{H}_{2} \mathrm{SO}_{4}, \mathrm{NaOH}, \mathrm{HCl} \mathrm{0,1} \mathrm{N,} \mathrm{H}_{3} \mathrm{BO}_{4}$, kertas saring, klorofoam dan pelarut heksana.

\section{Rancangan Penelitian}

Rancangan penelitian yang digunakan pada penelitian ini yaitu Rancangan Acak Kelompok (RAK) dengan menggunakan 5 perlakuan yaitu sampel udang yang didapat dari Receiving (P1), Deheading (P2), PND (P3), Washing III (P4) dan Freezing (P5). Ulangan berupa kelompok supplier ysng berbeda.

\section{Parameter Uji}

Parameter untuk mengatahui perubahan biokimia dilakukan pada saat bahan baku diterima di unit pengolahan dan pada saat setelah melewati semua alur produksi terpilih. Parameter pengamatan pada penelitian ini terdiri dari uji pH, TVB, TMA dan TPC. Untuk analisis proksimatmeliputi kadar air, kadar abu, kadar protein, kadar lemak dilakukan pada saat bahan baku diambil pada proses awal dan akhir.

\section{Analisis Data}

Untuk mengetahui pengaruh perbedaan terhadap perameter yang akan diamati maka dilakukan analisis ragam ANOVA (Analysis of Variance) untuk parameter suhu, $\mathrm{pH}, \mathrm{TVB}, \mathrm{TMA}$ dan TPC. Jika ditemukan perbedaan yang signifikan dilakukan dengan uji DMRT (Duncan Multiple Range Test).

\section{HASIL DAN PEMBAHASAN}

\begin{tabular}{lccccc}
\hline \multirow{2}{*}{ Parameter } & \multicolumn{5}{c}{ Rerata \pm SD } \\
\cline { 2 - 6 } & $\mathrm{P} 1$ & $\mathrm{P} 2$ & $\mathrm{P} 3$ & $\mathrm{P} 4$ & $\mathrm{P} 5$ \\
\hline Suhu $\left({ }^{\circ} \mathrm{C}\right)$ & $1,767 \pm 0,611^{\mathrm{a}}$ & $4,233 \pm 0,058^{\mathrm{b}}$ & $5,567 \pm 1,361^{\mathrm{c}}$ & $2,467 \pm 0,635^{\mathrm{a}}$ & $2,167 \pm 0,208^{\mathrm{a}}$ \\
pH & $6,83 \pm 0,513$ & $7,00 \pm 0,200$ & $6,87 \pm 0,058$ & $6,97 \pm 0,153$ & $6,87 \pm 0,058$ \\
TVB & $10,31 \pm 2,174^{\mathrm{c}}$ & $7,07 \pm 1,090^{\mathrm{b}}$ & $3,69 \pm 0,049^{\mathrm{a}}$ & $3,98 \pm 0,508^{\mathrm{a}}$ & $2,74 \pm 0,934^{\mathrm{a}}$ \\
$(\mathrm{mgN} / 100 \mathrm{~g})$ & & & & & \\
TMA & $3,75 \pm 1,543^{\mathrm{b}}$ & $2,14 \pm 1,371^{\mathrm{ab}}$ & $0,68 \pm 0,426^{\mathrm{a}}$ & $1,22 \pm 0,506^{\mathrm{a}}$ & $1,22 \pm 0,526^{\mathrm{a}}$ \\
$(\mathrm{mgN} / 100 \mathrm{~g})$ & & & & & \\
\hline
\end{tabular}




\begin{tabular}{llllll}
\hline TPC & $7,2 \times 10^{4}$ & $1,9 \times 10^{4}$ & $3,7 \times 10^{4}$ & $4,2 \times 10^{4}$ & $3,9 \times 10^{4}$ \\
$(\mathrm{CFU} / \mathrm{g})$ & & & & & \\
\hline
\end{tabular}

Keterangan: (P1): Receiving; (P2): Deheading; (P3): Peeling and Deveined; (P4): Washing III dan (P5): Freezing. Notasi huruf yang sama menunjukkan hasil menunjukkan hasil perbedaan tidak nyata dengan taraf signifikan $(\alpha=5 \%)$

\begin{tabular}{|c|c|c|}
\hline \multirow{2}{*}{ Parameter } & \multicolumn{2}{|c|}{ Alur Proses } \\
\hline & P1 & $\mathrm{P} 2$ \\
\hline Air & $78,66 \pm 5,763(\mathrm{bb})$ & $82,53 \pm 0,802(\mathrm{bb})$ \\
\hline $\mathrm{Abu}$ & $7,74 \pm 0,665(\mathrm{bk})$ & $2,65 \pm 0,080(\mathrm{bk})$ \\
\hline Protein & $52,71 \pm 12,600(\mathrm{bk})$ & $74,93 \pm 2,357(\mathrm{bk})$ \\
\hline Lemak & $22,66 \pm 1,167(\mathrm{bk})$ & $19,65 \pm 0,164$ (bk) \\
\hline
\end{tabular}

\section{Suhu Daging Udang Vaname}

Hasil analisis sidik ragam menunjukkan bahwa alur proses berbeda diikuti perbedaan yang signifikan $\left(F_{\text {hit }}>F_{\text {tab(0,05) }}\right)$ terhadap Suhu. Hasil dari uji DMRT menunjukkan bahwa antara alur proses P2 dan P3 secara signifikan berbeda dengan alur proses lainnya. Suhu pada daging udang pada proses P1 berkisar $1,767{ }^{\circ} \mathrm{C}$ kemudian meningkat pada proses $\mathrm{P} 2$ dan $\mathrm{P} 3$ berturut-turut $4,233{ }^{\circ} \mathrm{C}$ dan $5,567{ }^{\circ} \mathrm{C}$. Hal ini disebabkan adanya perpindahan panas dari pekerja yang dimana terjadi kontak langsung yang relatif lama dengan tangan pekerja. Pada proses P4 dan P5 suhu daging udangberangsur-angsur menurun berturut-turut $2,467{ }^{\circ} \mathrm{C}$ dan $2,167{ }^{\circ} \mathrm{C}$ disebabkan pada tahapan tersebut dilakukan penambahan es pada proses P4. Untuk P5 udang vaname terlebih dahulu dibekukan menggunakan $\mathrm{CPF}$ dengan suhu $-18^{\circ} \mathrm{C}$ kemudian dicairkan setelah diukur suhunya menjadi $2,167{ }^{\circ} \mathrm{C}$.

\section{Nilai derajat keasaman (pH)}

Nilai $\mathrm{pH}$ merupakan salah satu indikator yang digunakan untuk menentukan tingkat kesegaran hasil perikanan. Nilai derajat keasaman $(\mathrm{pH})$ yang diukur untuk menentukan tingkat kesegaran hasil perikanan secara kimiawi.Suhu yang terukur pada penelitian ini berkisar $0-10 \quad{ }^{\circ} \mathrm{C}$. Penangananudang vaname pada suhu rendah menyebabkan aktivitas enzim yang terdapat pada daging menjadi terhambat sehingga kemunduran mutunya berjalan lebih lambat. Semakin rendah suhu yang digunakan maka aktivitas enzim semakin terhambat.Seperti yang terlihat pada Tabel 1 nilai $\mathrm{pH}$ mulai dari awal proses hingga akhir proses mengalami penigkatan dan penurunan, akan tetapi berdasarkan hasil analisis statistikmenunjukkan bahwa nilai $\mathrm{pH}$ pada setiap tahapan alur proses tidak berbeda signifikan $\left(\mathrm{F}_{\text {hit }}<\mathrm{F}_{\text {tab(0,05) }}\right)$ ini menunjukkan bahwa udang tidak mengalami perubahan nilai $\mathrm{pH}$ yang signifikanselama proses rantai dingin.

\section{TVB-N}

Pada alur proses Receiving hingga Freezing menunjukkan nilai uji TVB-N rata-rata berturut-turut berada di kisaran 10,306; 7,067; 3,690; 3,983; dan 2,739 masing-masing untuk Receiving, Deheading, PND, Washing III dan Freezing. Nilai TVB-N pada semua alur 
proses sangat rendah. Hal ini mengindikaskan bahwa daging udang tidak banyak mengalami dekomposisi sehingga kualitas udang tetap terjaga. Semakin banyak daging udang terdekomposisi, maka semakin banyak pula ammonia yang dihasilkan. Untuk produk hasil perikanan yang belum diolah batas nilai TVB-N menurut Commision Regulation (2008)dalam Ruiz-Capillas et al. yang ditolerir paling banyak 35 $\mathrm{mgN} / 100 \mathrm{~g}$. Nilai TVB pada semua alur proses masih berada jauh dibawah batas $35 \mathrm{mgN} / 100 \mathrm{~g}$, dimana udang vaname tersebut masih sangat layak untuk dipasarkan dan dikonsumsi.

Nilai TVB-N pada alur proses Receiving memiliki nilai tertinggi (10,31 mgN/100g) kemudian berangsurangsur menurun pada proses berturutturut $(7,07 \mathrm{mgN} / 100 \mathrm{~g})$ dan $(3,69$ $\mathrm{mgN} / 100 \mathrm{~g}$ ) masing-masing untuk Deheading dan PND. Hal ini diduga karena hilangnya sejumlah bakteri yang berkontribusi terhadap senyawa volatil yang terdapat pada kepala, cangkang serta usus udang dan juga selama proses rantai dingin suhu tetap di bawah $10{ }^{\circ} \mathrm{C}$. Penelitian sebelumnya Clucas dan Ward (1996) yang merlaporkan bahwa suhu rendah $0-6 \quad{ }^{\circ} \mathrm{C}$ menyebabkan aktivitas mikroorganisme dan enzim penyebab pembusukan akan terganggu sehingga pembentukan basa volatil nitrogen yang diduga akibat reaksi kimia setelah proses post rigor mortis dan aktivitas bakteri juga akan terganggu.Botta (1995) menyatakan bahwa peningkatan kadar TVB-N dikarenakan oleh bertambahnya jumlah bakteri kontaminasi sehubungan dengan semakin berlanjutnya proses kemunduran mutu oleh mikroorganisme yang menghasilkan basa yang mudah menguap seperti amoniak.

\section{TMA-N}

TMAO secara alami terdapat pada serat daging hewan perairan. Jika hewan perairan mengalami kematian maka TMAO tereduksi menjadi TMA akibat adanya aktivitas enzim. Reaksi ini berperan penting dalam pembusukkan hasil perikanan yang disebabkan oleh bakteri. TMA merupakan salah satu senyawa volatil yang dapat dijadikan indikator kesegaran hewan perairan. Nilai TMA-N tertinggi dari alur proses rantai dingin udang vaname yaitu Receiving 3,75 $\mathrm{mgN} / 100 \mathrm{~g}$ kemudian berangsurangsur menurun hingga akhir proses (Freezing). Hasil analisis sidik ragam menunjukkan nilai TMA menunjukkan perbedaan signifikan $\left(\mathrm{F}_{\text {hit }}>\mathrm{F}_{\text {tab }(0,05)}\right)$. Selanjutnya uji DMRT alur proses P1 berbeda signifikan dengan P3, P4 dan P5. Disi lain antara P1 dan P2 tidak menunjukkan perbedaan, begitu pula dengan antara P3, P4 dan P5.

Banyak ahli berpendapat batasan kesegaran hasil perikanan yang dinilai dengan uji TMA yaitu $5 \mathrm{mgN} / 100 \mathrm{~g}$ daging (Montgomery et al., 1970 dalam Suwetja 1986). Menurut Suwetja (2011) TMA akan terhambat pembentukkannya pada hasil perikanan apabila dibekukan akan tetapi menurut Hebard et al (1982) TMA tidak dapat terbentuk dalam kadar yang cukup pada reaksi enzimatis, sama halnya dengan pembentukkan DMA dan FA. Pada penelitianGoncalves dan Gindri (2009) pada sampel Xiphopenaeus kroyeri senyawa Trimetilamin tidak terbentuk pada penyimpanan beku, akan tetapi senyawa dimetilamin dapat mebentuk dua kali lipat senyawa trimetilamin setelah 50 hari penyimpanan beku.

Penelitian sebelumnya yang dilakukan oleh Zhang et al. (2015) 
menyatakan bahwa meningkatnya kadar TVB-N dan TMA-N pada sampel udang vaname yang dikemas selama 180 hari dengan suhu $-18^{\circ} \mathrm{C}$ tetap berada di bawah $30 \mathrm{mgN} / 10 \mathrm{~g}$ dan $11 \mathrm{mgN} / 100 \mathrm{~g}$. Lebih lanjut dijelaskan bahwa meningkatnya kadar TVB-N disebabkan oleh enzim proteolitik menjadi asam karboksilat, asam sulfida, ammonia maupun jenis asam lain. Sasi et al. (2000) menyatakan bahwa TVB-N mudah larut dan terdiri dari senyawa-senyawa yang mudah menguap. Jiang (2000) mengungkapkan bahwa meningkatnya nilai TVB disebabkan adanya nukleotida yang mentransfer ATP sehingga berperan dalam penambahan jumlah ammonia dan volatil amin.

\section{TPC (Total Plate Count)}

Udang mengandung bakteri cukup banyak yang terkonsentrasi pada kepala, cangkang dan saluran pencernaan (Dwiari, 2008). Perubahan yang terjadi setelah udang mati yaitu terjadi perubahan biokimia dan mulai terjadi proses kemunduran mutu atau deterioration yang disebabkan oleh kegiatan autolisis, kimiawi dan bakterial. Jumlah total mikroba akan meningkat dengan adanya peningkatan suhu. Jeyasekaran et al. (2006) menyebutkan bahwa jumlah mikroba hasil perikanan yang segar berkisar antara 0,3 hingga 7,0 $\log \mathrm{CFU} / \mathrm{g}$ tergantung dari tingkat kontaminasi. Pada penelitian ini jumlah total mikroba pada daging udang pada semua tahapan alur proses masih berada di batasan menurut SNI 01-2705-1992 yaitu untuk udang mentah beku dengan kulit/tanpa kulit yaitu 5 x $10^{5}$ koloni/gram (BSN, 1992).

Nilai TPC udang vaname pada Receiving yaitu 7,2 x $10^{4} \mathrm{CFU} / \mathrm{g}$ atau 3,429 log CFU/g kemudian menurun pada
Deheading menjadi $1,9 \times 10^{4} \mathrm{CFU} / \mathrm{g}$ atau $1,115 \log \mathrm{CFU} / \mathrm{g}$ ini disebabkan oleh proses pemotongan kepala udang kemudian berdampak menurunnya jumlah bakteri total yang terdapat pada kepala udang.Hal ini selaras dengan pendapat Dwiari (2008) menyatakan bahwa bakteri yang terdapat pada tubuh hasil perikanan yang masih hidup jumlahnya tergantung pada lingkungan tempat hidup hewan perairan tersebut. Bakteri tersebut terpusat pada 3 tempat yaitu seluruh permukaan tubuh, kepala, dan isi perut.

Jumlah total mikroba meningkat pada $P N D$ menjadi $3,7 \times 10^{4} \mathrm{CFU} / \mathrm{g}$ atau $2,273 \log \mathrm{CFU} / \mathrm{g}$. Hal ini diduga karena udang vaname kontak langsung yang relatif lama dengan pekerja dan menyebabkan kontaminasi silang dan juga meningkatnya Suhu rata-rata daging udang vaname selama proses $P N D$ sehingga mempercepat siklus pertumbuhan mikrobial dari udang vaname tersebut.

Nilai TPC udang vaname setelah dilakukan perlakuan pencucian dengan larutan klorin 50 ppm menjadi 4,2 x $10^{4}$ $\mathrm{CFU} / \mathrm{g}$ atau 2,493 log $\mathrm{CFU} / \mathrm{g}$ dengan pencucian larutan klorin $(\mathrm{NaOCl})$ yang bersifat densifektan yang dimana pencucian ini dapat membunuh bakteri akibat kontaminasi yang terjadi pada saat pengelupasan kulit dan pembuangan usus. Kontaminasi ini dapat berasal dari pekerja, peralatan yang digunakan atau kondisi yang tidak steril.

Pada alur proses pembekuan (P5) nilai rata-rata TPC menurun menjadi 3,9 $\mathrm{x} \quad 10^{4} \mathrm{CFU} / \mathrm{g}$ atau 364log $\mathrm{CFU} / \mathrm{g}$. Menurunnya total mikroba pada tahap pembekuan disebabkan perubahan dan komposisi mikroorganisme dipengaruhi oleh suhu, jika suhu meningkat, maka kecepatan metabolisme naik dan pertumbuhan mikroorganisme akan cepat, 
sebaliknya bila suhu mengalami penurunan maka kecepatan metabolisme juga akan menurun dan pertumbuhan mikroorganisme akan lambat (Adawyah, 2007).

\section{Nilai Proksimat}

Udang vaname merupakan bahan pangan sumber protein hewani. Sebagai bahan pangan perlu untuk mengetahui kandungan nutrisi yang dapat diwakili oleh kandungan proksimat meliputi air, abu, protein dan lemak. Dalam penelitian ini, proksimat merupakan data penunjang khususnya informasi gizi setelah melewati serangkaian proses penanganan rantai dingin.

Keberadaan air pada bahan baku pangan terdapat dalam bentuk air bebas (available water) dan air terikat (bound water). Air bebas terdapat pada ruangruang antar sel dan plasma. Air bebas ini melarutkan berbagai vitamin, garam dan mineral dan senyawa-senyawa nitrogen tertentu. Jumlah air pada daging udang menempati urutan pertama atau komponen terbesar.

Seperti yang ditunujukkan pada Tabel 6 kadar air pada alur proses Receiving daging udang vaname adalah sebesar 78,66\%. Kemudian kadar air mengalami perubahan menjadi $82,53 \%$ pada proses Freezing. Hal ini diduga karena pada proses pembekuan arrest time yang tidak lebih dari dua jam (quick freezing). Menurut Adawyah Pembekuan cepat menghasilkan kristal-kristal kecil di dalam sel jaringan hasil perikanan. Oleh sebab itu, kemungkinan kerusakkan dinding sel sangat kecil sehingga pada saat dicairkan (di-thawing) cairan sel tidak akan mengalami drip loss.
Kadar abu udang vaname segar (P1) sebesar 7,74\% nilai ini tidak berbeda jauh dengan kadar abu udang vaname segar pada peneltian Pugalópez et al. (2013) yaitu 2,10-2,27\% berdasarkan basis basah sedangkan dalam basis kering 7,96-8,96\%, sedangkan kadar abu pada proses Freezing (P5) sebesar $2,65 \%$. Penurunan kadar abu ini dapat disebabkan pada saat di-thawing banyak kandungan gizi ikut keluar bersama air. Kemungkinan yang lain udang segar yang terdapat pada alur proses Receiving masih berbentuk head-onshell-on yang mengandung kalsium dan mineral lainnya yang disumbangkan dari kepala udang dan cangkang udang. Hal ini berarti kadar abu yang terdapat pada kepala, kulit dan usus ikut terbuang selaras dilakukannya proses tersebut.

Komponen hasil perikanan kedua yang penting adalah protein yang kadarnya secara umum $18-22 \%$ untuk basis basah dan 76,9-88,2\% untuk basis kering. Pada Tabel 8 menunjukkan kadar protein $\mathrm{P} 1$ adalah $52,71 \%$ kemudian menjadi 74,93\% setelah Freezing (P5). Menurunnya kandungan protein pada alur proses Receiving diduga karena adanya bakteri dan enzim proteolitik yang terdapat pada organ visceral udang yang dapat memecah protein. Katepsin dan kolagenase merupakan enzim proteolitik pada jeroan dan memiliki peranan penting dalam penguraian protein selama proses kemunduran mutu (Fentiana, 2009). Rendahnya kandungan protein juga diduga karena udang mengalami drip loss (cairan yang keluar dari produk) yang terjadi pada saat thawing. Menurut Boyd dan Ryder (2000) saat pembekuan terjadi denaturasi protein, hal ini bukan hanya menyebabkan protein kehilangan fungsinya sebagai enzim, tetapi juga 
kehilangan kemampuannya dalam mengikat air "water-holding".

Perbedaan kadar lemak pada awal proses (P1) yaitu 22,66\% dan akhir proses (P5) 19,65\% diduga karena terikut keluarnya lemak yang larut dalam air. Hal ini didukung oleh Lehninger (1982) yang menyatakan bahwa terdapat beberapa lemak yang berikatan spesifik dengan protein yang membentuk lipoprotein. Membran luar lipoprotein yang bersifat hidrofilik menghadap ke air dan menjadikan struktur yang kaya akan lipida ini larut dalam air. Handayani (2003) dalam Sari (2010) menyatakan bahwa selama penyimpanan produk beku akan terjadi perubahan mikrosturtur yang terlihat pada sebagian rongga membentuk parit atau saluran, sehingga air atau lemak akan mudah mengalir keluar saat thawing.

\section{KESIMPULAN}

Berdasarkan hasildan pembahasan dapat ditarik kesimpulan sebagai berikut:

1. Terdapat perubahan biokimia udang vaname dengan parameter masingmasing TVB dan TMA ditandai dengan adanya perbedaan signifikan pada serangkaian alur proses rantai dingin. Nilai tertinggi TVB dan TMA terdapat pada alur proses Receiving (P1), masing-masing 10,31 mgN/100 gr dan 3,75 mgN/100 gr. Pembekuan cepat (Quick freezing) dengan Contact Plate Freezing berdampak baik terhadap kesegaran/mutu udang ditandai dengan rendahnya nilai TVB dan TMA pada alur proses Freezing (P5), masing-masing 2,74 mgN/100 gr dan 1,22 mgN/100 gr.

2. Terdapat perubahan mikrobial udang vaname dengan TPC ditandai dengan adanya perbedaan signifikan pada serangkaian alur proses rantai dingin. Nilai TPC tertinggi terdapat pada alur proses Receiving (P1) 7,2 × $10^{4}$ $\mathrm{CFU} / \mathrm{g}$ dan nilai terendah pada alur proses Deheading (P2) 1,9 x $10^{4}$ $\mathrm{CFU} / \mathrm{g}$.

3. Kandungan proksimat udang vaname setelah melewati alur proses rantai dingin dalam produksi udang beku ekspor menunjukkan perubahan. Adapun perubahan yang terjadi yaitu peningkatan kadar air dan juga kadar protein, disisi lain kadar abu dan lemak mengalami penurunan.

\section{DAFTAR PUSTAKA}

Adawyah R. 2007. Pengolahan dan Pengawetan Ikan. Edisi pertama. Hal 38-39. PT Bumi Aksara. Jakarta

Botta JR. 1995. Freshness Quality of Seafoods. Chemistry, Processing Technology and Quality, Jurnal of Spinger. Pp 140-167

[BSN] Badan Standarisasi Nasional. 1991. Standar Nasional Indonesia. 01-2705-1992. Udang Beku. BSN. Jakarta.

[BSN] Badan Standarisasi Nasional. 2009. Standar Nasional Indonesia. 2354.8:2009. Cara Uji Kimia Bagian 8: Penentuan Kadar Total Volatile Base Nitrogen (TVB-N) dan Trimetil Amin Nitrogen (TMA-N) pada Produk Perikanan. BSN. Jakarta.

DKP. 2005. Revitalisasi Perikanan Budidaya 2006-2009.

Fentiana N. 2009. Pernanan Enzim Protease Jeroan Ikan Bandeng (Chanos chanos) dalam Proses 
Kemunduran Mutu [Skripsi]. Bogor: IPB

Goncalves AA \& Gindri Jr CSG. 2009. The Effect of Glaze Uptake on Storage Quality of Frozen Shrimp. Journal of Food Engineering 90, 285-290.

Handayani. 2001. Pengaruh Penambahan Titanium Dioksida $\left(\mathrm{TiO}_{2}\right)$ Pada daging Merah Yellow Fin Tuna. $34 \mathrm{Hal}$.

Hebard, CE, Flick GJ and Martin RE. 1982 Occurance and Significance of Trimethylamine oxide and its devartives in fish and shellfish. In Chemistry and Biochemistry of Marine Food Products p149. AVI Publishing Company Westport. Connecticut.

[KKP] Kementrian Kelautan dan Perikanan. 2017. Statistik volume Produksi Udang 2010-2015. Direktorat Jendral Perikanan Budidaya, Kementrian Kelautan dan Perikanan.

[KKP] Kementrian Kelautan dan Perikanan. 2014. Statistik volume Produksi Budidaya Udang Sulawesi tenggara 2000-2013. Direktorat Jendral Perikanan Budidaya, Kementrian Kelautan dan Perikanan.

Purwaningsih. 1995. Teknologi pembekuan Udang. PT. Penebar Swadaya. Jakarta.

Sari SF. 2010. Pengaruh Perbedaan Metode Pencairan (Thawing) terhadap Kualitas Kimia Daging Abaloon (Haliotis asinine) yang telah Dibekukan[Skripsi]. Kendari: Universitas Halu Oleo.
Suwetja IK. 2011. Biokimia Hasil Perikanan. Jakarta: Media Prima Aksara.

Zhang LX, Li W, Lu H, Shen, Luo Y. 2015. Quality predictive models ofgrass carp (Ctenopharyn godonidellus) at different temperatures during storage. 